Mediterranean Journal of Humanities mjh.akdeniz.edu.tr IV/1, 2014, 285-299

\title{
Memet Baydur Oyunlarında Aydın Bunalımı
}

\author{
Intellectual Crisis in Baydur's Plays
}

\section{Halil İbrahim YÜCEL*}

Öz: Aydın, vücut bulduğu topluma ayna görevi üstlenmesi gereken ve beslendiği toplumun problemli yönlerini, entelektüel donanımıyla, eleştirel aklın süzgecinden geçirerek, düzeltme yolunda öncülük etmesi lazım gelen kişidir. Bu misyonu gereği o, sorumlu bulunduğu topluma karşı hassas olmak durumundadır. Ancak, tarih içerisinde muhtelif zamanlarda vuku bulan olumsuz koşullar, aydın denen varlığ bu görevinden zaman zaman uzaklaştırmıştır. Memet Baydur, 1951-2001 yılları arasında Türkiye'de ve dünyanın çeşitli ülkelerinde yaşamış, kendini aydın olarak tanımlayan ve onun deyimiyle "içinden çıktığı" aydın çevresini çoğu kez ironik ve sert dille eleştiren bir yazın adamıdır. Daha ziyade tiyatro oyunları ile tanınan Baydur, deneme yazıları, çeviriler ve öykü alanlarında da eserler vermiştir. 1980 sonrası en üretken yazarların başında gelen ödüllü tiyatro sanatçısı, dönemin sert koşulları ve bunalımını, ülke içinden olduğu kadar dışarıdan da gözleme firsatı bulmuş ve oyunlarının ana temini, darbe döneminin yarattığı aydın figürleri üzerine kurmuştur. Biz de bu doğrultuda makalemize yön vererek, yazarın tiyatro oyunlarından hareketle, 1980 darbesinin yarattığı aydın profilini irdelemeye gayret edeceğiz.

Anahtar sözcükler: Aydın, Limon, Cumhuriyet Kızı, Maskeli Süvari, 12 Eylül 1980 darbesi

Abstract: An intellectual is the one who needs to accept the responsibility to enlighten his/her society and leads through critically reasoning out the problematic sides of his/her society with his/her intellectual gift and knowledge. For this duty, s/he is supposed to be sensitive toward the society s/he is responsible to. However, the poor conditions at times in history, keep the intellectual away from his/her duty. Memet Baydur, lived in Turkey and various countries between 1951 and 2001, is a literary man who defines himself as an 'intellectual' and most of the time harshly and ironically criticizes the intellectual community he belongs to - in his own words, "that he originated from". Rather recognized by his plays, Baydur also worked on essays, translations and stories. Being one of the leading playwrights who produced the most literary work in the period after 1980, he found the opportunity to observe the hard conditions and depression of the period not just from the inside but also outside the country and formed the main themes of his plays on the intellectual figures that the period of the military coup had created. In line with Baydur's plays, shaping the path we follow we attempt to analyze the profile of the intellectual that the 1980 military coup produced.

Keywords: Intellectual, Lemon, Cumhuriyet Kızı, Maskeli Süvari, the Military Coup in 12 September 1980

\section{Giriş}

"Aydın" kavramının tanımı ve aydın kimsenin niteliklerinin ortaya konması sorunu, tarih boyu, bilhassa filozof ve sosyologlar tarafından cevap aranan önemli bir problem alanı olmuştur. Süreç içerisinde yapılan birçok açıklamaya rağmen, terimin açık bir tanımını yapmak, evrensel anlamda aydını vizyon ve misyonlarıyla ortaya koymak zordur. Nitekim Shumpeter bu konuda

\footnotetext{
* M.A. Akdeniz Üniversitesi, Edebiyat Fakültesi, Türk Dili ve Edebiyatı Bölümü, Antalya, hiyucell@gmail.com
} 
"Entelektüel, tarif edilmesi kolay olamayan sosyal bir tip" ifadesini dillendirir. Hatta tarifindeki zorluğu entelektüelin özelliklerinden biri olarak addeder (Meriç, 2007, 17).

Aydın tanımını kimin yapacağı, vasıflarını kimin, hangi ölçüte göre değerlendirip belirleyeceği, kimlerin yahut hangi grubun aydın sınıfa dâhil edileceği; bu sorulara cevap arayan kişiye, topluma ve ideolojiye göre değişecektir.

Türkiye'de "aydın" ve onun ağabeyi konumundaki "münevver" sözcükleri, Batı toplum tarihi içinde ortaya çıkan intellectuel-intellectuals, intelligentsia, literati ve les clercs gibi ayrınt1lı kavramları daha kolay irdelemek için, tek bir terim olarak kullanılmıştır (Mardin, 1984, 9).

Türk Dil Kurumu, Güncel Türkçe Sözlüğ̈̈'nde aydın1; "kültürlü, okumuş, görgülü ileri düşünceli kimse, münevver, entelektüel" olarak tanımlar. "Münevver" sözcüğü ise, "aydın kimse" olarak yer alır (Devellioğlu, 2007, 727).

Ortaçağ sonlarına doğru Latince intellectualis biçiminde türeyen "entelektüel” kelimesi, "soyut alanda yer tutan ve mevcut fikir ve düşüncelerle hesaplaşma içinde olan, kendi fikirlerini oluşturan bir kimse" anlamındadır. Bu bakımdan, 17. yüzyılda ortaya çıkan ve Fransızca "éclairé" sıfatından türeyen "bilgi edinme ve eğitim yoluyla zihni aydınlanmış kişı" anlamındaki aydın kavramından farklıdır. Yani "entelektüel” üretici konumda iken, "aydın" tüketici konumdadır (Kılıçbay, 1995, 175-179).

Aydın kimliğinin bugünkü rolüne bürünmesinde ve bu sınıfın toplumlar üzerindeki etkisinin görülmesinde, Fransa'da 1884'te yaşanan “Dreyfus Davasi” ve burada ünlü Fransız yazar Emile Zola'nın tavrı etkili olmuştur. Yahudi bir Fransız askeri olan Yüzbaşı Dreyfus, Paris’te bir Alman askerî ataşesinin çöp kutusunda bulunup Fransız ordusuna ait bilgiler içeren nottan sorumlu tutulur ve üstleri tarafindan vatan hainliği ile suçlanır. Yazının yüzbaşıya ait olmamasına karşın Yahudi kökeni nedeniyle, dönemin ırkçı ve bağnaz rejimi Dreyfus’u suçlu görür ve rütbelerini sökerek, onu şeytan adasında ömür boyu sürgüne mahkûm eder. Zamanla ordu içindeki üst kademelerin değişmesiyle bir subay, Dreyfus'un masumiyetini anlar ve üstlerine bilgi verir. Ancak dediklerine pek kulak asılmadığı gibi önce tehditler ve ardından sürgün cezası alır. Durum böyle iken, davaya karşı en sert tepkiyi bir Fransız aydını olan Zola verir. Dreyfus'un suçsuzluğuna inandığını her yayınında savunan Zola, ona yapılanların ırkçı nedenlerden başka bir şey olmadığını söyler. Zola bu konudaki en sert yazısını 13 Ocak 1898'de Clemenceau'nun gazetesi L’Aurore'de “Cumhurbaşkanı Felix Faure'ye Açık Mektup” olarak yayımlar. Yazıda sürekli vurgulanan "J'Accuse! (Suçluyorum!)” söylemi, aynı zamanda yazının başlığıdır. İşte bu mektup Fransa' da aydın hareketinin doğuşuna zemin hazırlar. Zola orduya hakaretten yargılandığı sırada, Dreyfus'un masumiyeti üzerine and içerek, savunmasını "Bir gün Fransa bana teşekkür edecektir" sözleriyle noktalar. Nitekim böyle de olur. Dreyfus'u mahkûm ettirenlerin aslında gerçek hainler olduğu ispatlanır. Zola bu emin duruşu ile bir aydınlanma filozofu gibi kitlelere öncülük etmiştir (Baysan, 2002, 181-195).

Emile Zola'dan hareketle, aydının görevi sadece düşünsel anlamda değildir. Sartre'ın ifadesiyle aydın, "hem kendi alanında hem de alanının dışında işlere burnunu sokan kişidir" (Meriç, 2007, 17). O, daha güzel ve âdil bir dünya düşleyen ve bu uğurda düşünen, sorgulayan eleştiren insandır. Eleştiri oklarını iktidarlara yöneltmekten korkmayan kişidir (www.emeginsanati2. blogcu.com/adil-okay-aydin-ve-toplum-ii/5507059).

Her toplumun aydın tanım ve niteliği kendine göre farklılıklar göstermektedir. Az gelişmiş milletlerde hala devlet memuru olan kimselere aydın gözüyle bakılırken daha ileri olanlarda ise bu kimlik, salt bilginin ötesine geçmiş ve yaşadığı toplum için bilgi, teknoloji üreten, çağın sorunlarına çözüm arayan kişiler için kullanılır olmuştur. 
Türk toplumunda da aydın, imparatorluktan Cumhuriyete farklı görevlerle evrilerek günümüze ulaşır. Osmanlı İmparatorluğunun, ilim ve fen olarak Batılı devletlerin gerisinde kaldığını fark ettiği Tanzimat Dönemi’nde, Fransa'ya kabiliyetli öğrenciler gönderilir. Ülkenin entelektüel birikiminden yararlanarak aydınlanması amaçlanan genç dimağların, imparatorluğu ayağa kaldıracağı inancı hâkimdir. Yani bu devir aydınlarının, genel hatları itibarıyla ıslahatçı bir yapıda olduklarını görürüz. İmparatorluğun iyiden iyiye zayıflaması sonrası ise, bir kısım ülke aydını ihtilâlci bir çehreye bürünür. Yeni bir devlet ve yeni bir rejimin tohumlarının atılmasına katk1 sağlar. Kurulan yeni devletin modern dünyaya ayak uydurması çalışmaları, yine onlara düşer. İnkılâpların teori ve pratiğinin yanında, halkın onları benimsemesi noktasında çalışmalar yaparlar. Cumhuriyetin ilk zamanlarından günümüze dek uzanan yıllarda ise, kimi aydınları, dönemin popüler ideolojisi olan sosyalist çatı altında, devrimci karakterde görürüz. Türk düşünce dünyasının önemli mütefekkirlerinden Cemil Meriç bu değişimini şöyle özetler. "Türk aydını her mevsim bir başka meçhûlün sevdalısı. Geçen asrın ortalarında ıslahatçıdır, sonra ihtilalci olur, sonra inkılâpçı. Ve tarih 27 Mayıs'tan (1960 darbesi) bu yana, yeni kahramanın zaferine alkış tutar: Devrimci. Artık iki hücreli bir mahpesteyiz; hücrenin biri devrimcilerin, öteki gericilerin" (Meriç, 2007, 111).

Aydınlar toplumu bilgilendirici ve yönlendirici konumda yer alırken, tarihsel süreç içerisinde çeşitli zamanlarda otorite tarafından susturulmuşlardır. Türk tarihine baktığımız zaman; monarşik yönetimin istibdat dönemlerinde ve Cumhuriyet yıllarında demokrasiyi baltalayan darbe süreçlerinde, Türk aydını görevlerini yapmaktan alıkonmuş ve hatta şiddetle cezalandırılmıştır.

Makalemizle alakalı olan 12 Eylül Askeri Darbesi bu dönemlerden biridir. 12 Eylül 1980 yılında gerçekleşen darbede, binlerce eğitim elemanı, yazar ve devlet görevlisi ya işten atılmış ya da sürgün edilmiştir. Bunun yanında bine yakın film sakıncalı bulunarak yasaklanmış, binlerce kitap toplanarak imha edilmiş, basın elemanlarına çok sayıda dava açılarak, Türk basını sansüre tabi tutulmuştur. Darbeyle gelen olumsuz koşullar, sokağa çıkma yasakları, şüpheli görülen herkesin gözaltına alınması ve bu süreçler, toplumu güvensizliğe ve yalnızlığa itmiştir.

İşte bu şartlarda aydın, toplumu adına bir şeyler yapamamış; yalnızlık, sansür ve baskıyla örülü hücresinde yabancılaşmaya mahkûm bırakılmıştır. Aydınlığın karanlığa hapsolduğu o günler ise, birçok sahte aydıncığın türemesine yol açmış, aydın olgusunu bildiğimiz anlamından çok başka bir yere taşımıştır. Dönemin önemli sanat adamlarından Memet Baydur ise oyunlarında tam da bu hususlara parmak basarak, rejimin yarattığı aydın tiplerinin çaresizliği ve sefaletini gözler önüne serip onları ince bir hicve tabi tutmuştur.

“Baydur örgütlü devlet baskısının Türkiye'de son derece etkili olduğu bir
dönemde oyun yazmaya başlamıştır. Doğgru olarak bilinenlerin dumanlı,
sisli bir ortamda havaya asılı kaldığı, her durumda her çeşit eylemin
anlamının ve öneminin belirsizleştiği, inançların güven vericiliğini yitir-
diği, bireyin topluma, toplumun bireye yabancılaştı̆̆g, suskun, bungun
bir dönemdir bu. Baydur tiyatrosunun bir dolu kişisi, 12 Eylül’ün, toplu-
mu sindirme, eylemsizleştirme yolunda kazandiğl psikolojik başarının
ürünleridir” (Yüksel, 1997, 134).

Memet Baydur'un hemen her oyununda bu dönemin izlerine rastlamak ve o buhranlı dönemin yarattığı yeni insan ve aydın figürlerini görmek mümkündür.

\section{Sıkı Yönetim Ürünü Yeni Aydın Profilleri}

Memet Baydur 1951-2001 yılları arasındaki ömrüne, çoğunluğu tiyatro oyunu olmak üzere 
öyküler, denemeler ve çeviriler gibi birçok eser sığdırmıştır. Bu yönüyle o, yakın dönem tiyatromuzun en üretken ve öne çıkan yazarlarından biridir. Hayatının önemli bölümü, eşinin büyükelçi olması dolayısıyla ülke dışında geçmiş ve bu durum ona dönemin Türkiye'sini içeriden olduğu kadar dişarıdan da gözlemleyebilme şansı vermiştir.

Yazdığı oyunlar, yurt içi ve yurt dışında pek çok kez sahnelenen yazar, bunlarla çeşitli ödüllere layık görülmüştür. Aynı zamanda bir edebiyat ve sinema aşığı olan Baydur'un geniş kültür yelpazesi hemen her oyununda hissedilir.

“... Yola çıkarken yani 1978'de ilk oyunumu yazmayı kafama koyduğum zaman kafamda bir fresko vardl. Oyunlardan oluşan 25-30 oyunluk bütünüyle Türkiye'yi anlatan, tabii benim görebileceğim Türkiye'yi anlatan, ancak yan yana gelirlerse o 25-30 oyun büyük bir oyunun parçaları olarak anlatabileceğim bir genel, kaba hatlartyla kafamda olan bir fresko, bir duvar resmi, bir mozaik vardi" (Şener, et alii, 2002, 60-61).

Kendini de bir aydın olarak gördüğünü söyleyen yazar, iyi tanıdığı bu cemiyeti yine en sert kendi eleştirmiştir. 1980 darbesi ve sonrasında Türk aydınının durumu, onun oyunlarında yer bulur.

Baydur, darbe sonrası pasifize olan, kimliksizleșen aydınları, mizahi ancak sert bir dille hicveder. Üzerlerindeki sorumluluğu yerine getiremedikleri için kendilerine ve topluma yabancılaşan bu aydınlar, aynı dönemde sistemin yarattığı aydınımsı-burjuva tiplerin de önüne geçememişlerdir. Bu dönem Türkiye’si ve insanı "Baydurca" bir plan dâhilinde oyunlaşır.

\section{Bir Cins Sayıklama Güldestesi “Limon”}

Memet Baydur’un ilk oyunu olan “Limon”, Adalet Ağaoğlu aracıllğı ile Müşfik Kenter'e ulaşarak, 1982 yılında sahnelenir ve hem yazıcısına hem de yönetmenine ödül getirir. Bu oyunla yazın dünyasına giriş yapan Baydur, oyunu sahneleyen Müşfik Kenter için, "Müsşik Ăgabey olmasayd, ben oyun yazarı olmayacaktım” der (Şener, et alii, 2002, 15).

"Limon” genel hatlarıyla, kimi meteorolojik kimi sosyal bir takım şartlardan aynı dört duvar içine sıkışan kişilerin, toplumsal rollerini sürekli değiştirerek çözülmesi güç bir "oyun içinde oyuna” girişmesini anlatır. Karakterler; Muhsin, Aziz, Necip, Aslı, Berfinaz, Engin, Sevda ve 2. perdede göreceğimiz küçük Limon'dur. Oyun, yazarın, aile üyelerinden Oğuz Atay'a, Nebî'den Cervantes'e, yerli ve yabancı birçok yazara teşekkürü ile başlar.

Evin salonunda geçen 1. perdede dekor, ince bir zevkin ürünüdür. Kütüphane, saksafon, satranç tahtası, radyo, içki dolabı, av tüfeği, daktilo gibi aksesuarların bulunduğu salon, oyun kişilerinin seçkin kimliğini yansıtır.

Muhsin, hava muhalefeti nedeniyle hareket etmeyen trende beklerken karşılaştığ emekli avukat Necip Bey'i, istasyonda başlayan içkili sohbete devam etmek maksadıyla evine getirir. Muhsin ile aynı evi paylaşan Aziz ise, yıllarca reklam filmi çektikten sonra nihayet ilk uzun metrajlı denemesini yapmış ve bunu tartışmak için arkadaşlarını bekleyen bir sanat adamıdır. Aziz ve Necip tanışıp konuşurken, Muhsin onlara içki servisini üstlenir.

Sohbet derinleşirken, Aziz'in sürekli Necip'in ismini unutması, ileride olacakların habercisidir. Kapının çalmasıyla ev ahalisine bir kişi daha dâhil olacaktır. Bu yeni misafir, yıllarca Aziz'le görüşmedikten sonra önemli bir şey söylemek için gelen Aslı'dır. Kapı, fonksiyonel bir dekor unsurudur. Zira oyun süresince diyalogların monotonlaşmasına ve kişilerin içinde oldukları oyun içinde oyundan uzaklaşmasına müsaade etmeyecektir. Eve her gelen, garip bir şekilde bunun bir parçası olacaktır. Aslı'nın eve gelişiyle bu durum başlar. Emekli Avukat Necip Bey, 
Aziz'in "babacan, cahil, çakırkeyif, güngörmüşs ve hoşgörülen" akrabasıdır artık. Muhsin ise Necip Bey'in oğludur. Aslı, yazar tarafindan "uzun, kumral, güzel- ya da onun gibi bir şey-ama bitkin” olarak tasvir edilir. Aslı Aziz’e çok önemli bir şey söylemek için gelmiştir ancak gerek diğer kişilerin araya girmesi gerekse onun da bu garip oyunlar silsilesine katılması sonucu bu önemli şey söylenmez. Genç kadın bir uyarıcı görevinde olmasına rağmen, oyundaki susturulmuş aydın imajını verir.

İçkili sohbet devam ederken, yeniden kapı çalar. Gelen, oğlu Oğuz'u arayan Berfinaz teyzedir. Yetmiş yaşlarında, gözlüklü ve başörtülü olarak betimlenen Berfinaz teyzenin gelişiyle oyun, başka bir çehrede yeniden başlar. Artık Aslı, Necip ve Muhsin'in akrabası rolündedir ve ailenin evde kalmış kızıdır. Necip Bey ise, Muhsin'in iş yerinden arkadaşı ve muhasebe müdürüdür. O gün de Aslı'yı istemek için oradadır. Okulunu düşündüğü için bu işe pek gönlü olmayan Aslı'ya Berfinaz teyzenin söyledikleri, oyunun çözümü için önemlidir.

Berfinaz: A kızım, düşündügün şeye bak. Bu zamanda okuyup da ne olacak? Işste Oğuz, işte Aziz, işte Muhsin. Okudular da ne oldu sanki? Bir baltaya sap olamadılar, işleri güçleri laklaklak içip, her şeyle alay etmek. Okumak, tahsil filan eskiden bir işe yarardl. Bir anlamı ve önemi vardı diplomaların. O zamanlar... (Baydur, 2009, 20).

Aydın olmaya giden yolun başı sayılan okul, artık eskisi kadar nitelikli insanlar yetiştirememektedir. Yahut mezun insanlar sistemin dişlileri arasında yitmeyecek kadar güçlü kalamıyorlardır. Yazarın diyaloğu bunu tenkit eder niteliktedir.

Necip Bey, ilk defası burada olmak üzere birkaç kez bu oyundan çıkmak ister ancak diğer karakterlerce buna izin verilmez. Çünkü onlar gerçeklerle yüzleşmekten korkarlar. Necip ise, sinmekten çok sisteme karşı durmak düsturuyla hareket eden bir insandır. Nitekim o, avukatlıktan emekli olmadan önce, "iki kere hâkime hakaretten, bir kez kasten yangın çıkartmaktan üç kez mahkûm" olmuştur. Necip'i içine döndüren olay, üzerindeki baskı değil çocuğunu kaybetmesidir. Karamsarlık ve sıkıntı, oyun kişilerine ve ortama sinmiştir.

Kişiler arasında süren sohbet, ünlü ressam ve yönetmenlerden açılan bahisler ve klasik edebiyattan alıntılarla çeşitlenir, Batı müziği eşliğinde Fransız konyağı ve başka çeşit içkiler içilerek devam eder. Bu garip oyunun başlatıcısı olan Aziz "kafasının ve yüreğinin" dolu olduğunu söylerken, onun yaşadığı aydın buhranını görmek mümkündür.

Aziz ve onun gibiler, yapmak istediklerini üzerlerindeki baskı sonucu gerçekleştirememiş, bu nedenle kendilerine ve çevrelerine yabancılaşmışlardır. Gerçeklerden kaçmanın ve çevreyle bir şekilde iletişim kurmanın tek yolu olarak da içkiyi kullanırlar. Onlar eskiden toplumsal bir uğraş içerisinde iken, şu anda yalnızca Berfinaz teyzenin de söylediği gibi, "laklaklak” içip her şey üzerine gevezelik ederler. Sevda Şener bu durumu, 12 Eylül döneminde aydınlar arasında yaygınlaşan "suskunluğun gevezeliği" olarak tanımlar (Şener, et alii, 2002, 27).

Kapının tekrar çalmasıyla, yirmi yaşlarında iki zeki ve çokbilmiş genç, Sevda ve Engin oyuna dâhil olurlar. Bu pırıltılı gençler, yazarın tasviriyle, gülmeleri de somurtmaları gibi içten olan insanlardır. Yine de gereğinden fazla alay eder gibilerdir. Engin içinde saka kuşu olan bir kafesle, Sevda ise içinde viski ve Fransız konyağı olan bir kese kâğıdıyla gelir. Onların gelişiyle oyun yine baştan yazılır. Birer öğrenci olan Sevda ile Engin iki yıllık nişanlı iken, Necip üç kitap sahibi bir şairdir. Aslı ile Muhsin'i de sevgili rolünde görürüz. Klasik şiirden bir beyitle yapılan giriş sonrası, Sevda o gün okulda yaşadıkları tartışmaları anlatmaya başlar. Sinemadan, tangodan çıkan konu, "yetmiş iki mesele üzerinden bağırıp çă̆ırmalı bir tartışma"ya dönüşmüştür. Burada kastedilen, darbe öncesi üniversite gençliğinin "milliyetç̧" ve "sosyalist” saflara 
bölünmüşlügüdür. Yazarın "yetmiş iki mesele" sözüyle kastettiği, "yetmiş iki millet” deyimidir.

Sevda ve Engin aracılığıyla, dönemin üniversite gençliğinin durumu bize verilmeye çalışılır. Üniversitedeki tartışmaların kavgaya dönüşmesi, bir konu bağlanmadan diğerine geçilip bağrış çağırışlara mahal vermesi bunu anlatır. Başlarda zeki, çevreye apaçık gözlerle bakan bu gençler, oyun ilerledikçe karamsarlaşıp bitkin düşeceklerdir. Oyun içinde Sevda ve Engin'in değişimi ve darbe dönemi gençlerinin geçmişi-geleceği, ironik bir şekilde benzerdir. Sohbet çoğu kez, belki içinde bulunanların dahi anlayamayacağı kadar kopuk sürerken, Muhsin tozlu radyoyu açar. Radyoda bir piyes oynanmaktadır. Bu piyes durulan ortamı birden hareketlendirir. Okuyucuya evde yaşananları anlama olanağı verir.

Radyo: "Bir halkı ortadan kaldırmak için hafizasını yok ederek işe başlanır anlıyor musun?! Kitaplarını, tarihlerini, kültürlerini yok ederler. Başkaları... Onlara başka kitaplar yazar, başka bir kültür verir, başka bir tarih uydurur. Işste George, burada böyle yazıyor. Hüznün, umutsuzluğun, unutuşun dikte ettiği bir ölüm kitabı bu. Marie’ye bunu anlatmaya çalışıyordum ki...” (Baydur, 2009, 24-25).

Muhsin'in radyoyu kapatmasıyla ortalıkta bir hareketlenme görülür. Oyun kişileri içinde yalnız Muhsin ve Aslı piyesi dinlemek ister ve Aslı Muhsin'e radyoyu tekrar açması için baskı yapar.

Radyo: “...anllyor musun George, anllyor musun? Önce belleğimizi yok edecekler. Kitaplarımızl, tarihimizi, kültürümüzü yok edecekler. Bütün bunları bizi kurtarmak adına yapacaklar. Birileri... başka kitaplar yazacak... başka oyunlar, başka bir kültür, başka bir tarih uyduracaklar... öylesine pazarlanacak ki her şey, onlara inanacağız... bizim sonumuz George... bizim sonumuz...” (Muhsin radyoyu kapatır) Solak insanlar sendikası... (Baydur, 2009, 26).

Bu radyo yayını, oyun içindeki yabancılaşmanın sebebini açıklar niteliktedir. Darbe döneminde kitaplar yakılıp düşüncelere kelepçe takılmaya çalışılırken bu aydınlar, silinen hafizalarını gizlemek için bu oyuna girişirler. Yazar bu durumu, ileride yazacağı bir oyunda (Maskeli Süvari) okuyucuyla paylaşacaktır.

Maskeli: Neyi anlatiyordu o oyun?

Atilla: Hangi oyun?

Maskeli: Geçenlerde festivalde seyrettiğin oyun...

Atilla: Hiçbir şey anlatmıyordu. Unutmak üstüne bir oyunmuş. Yazarı

öyle iddia ediyor. Hafiza kaybının oyun oynanarak kamufle edilişi filan

diyordu bir eleştirmen! Kötüü, faşiiist, eylüliiist, on para etmez, yazınsal, sanatsal ve teatral on paralı değeri olmayan bir oyunu nasl sahnelerler, üstelik ödül bile vermişler yazarına. Bir komplo bu. Resmen bir sabote!

(Baydur, 2009, 301).

Baydur'un değindiği kişiler, sol fraksiyona ait aydın tabakasıdır. Darbe döneminin baskısı altında ezilen sol aydınlar, Sovyet-Sosyalist Rus rejiminin yıkılmasıyla ikinci büyük darbeyi yemiş ve deyim yerindeyse küsmüşlerdir. Yaşadığı topluma katkı veremeyen bu insanlar, seçkinliğini devam ettirirken, sosyal görevlerindense giderek uzaklaşmışlardır. Konuşmayı sürdürürler lâkin dilleri ilim saçmıyordur artık.

Kişiler de, oyun boyunca doğaçlama bir şekilde konudan konuya atlayarak sohbet ederler. Yer yer gereksiz ama çok konuşurlar. Hemen her konu üzerinden espri çıkarırlar, bolca şaka 
yaparlar. Konunun başını unutacak denli saçmalaşır meseleler. Kendi gevezelikleri içinde kaybolurlar. Bu durum, ileride Aziz'in de kâğıda dökeceği gibi; "bir saçmalar derlemesi... bir cins sayıklama güldestesi”dir. O, içinde olduğu karanlığın farkındadır. Aslı kendi kötü durumundan Aziz'e sığınarak kurtulacağını düşünmesine rağmen, onun yalnızlı̆̆ 1 ve tutarsızlığ i ikiliyi oyun sonlarında yeniden tanışmaya itecek kadar birbirinden uzaklaştırır. Aziz daktiloya yazdığı ufak bir parçayla kendinden ümidi kestiğini bildirir ancak okuyucuyu bu konuda diriltmeye gayret eder. Bunu bir çeşit aydın sorumluluğu saymak mümkündür.

“... Seni de sevgili okur, kendime, kendi zamanıma uygulamak isterdim. Bunlar kötü zamanlar. Renksiz bir fotoğraf gibi çekildin kendi klyına. Patiskalara sı̆̆ındın. Ah, DOĞU! İlintisiz doyumsuzlar diyarı! Herkes 'ispat hakkı' peşinde yirmi bin fersah. Biliyorum ben-adam-olmam, ya siz?” (Baydur, 2009, 34).

Necip ise trenin kalkması halinde bunların hiçbirinin olmayacağını düşünmektedir. Tren ve dolayısıyla yolculuk kinayelidir metinde. $\mathrm{O}$, aydınlar için bir değişme, ülkeyi ve dünyayı da değiştirme serüvenidir. Yasakların olmadığı, kendilerini yaşadıkları bir yolculuktur bu. Ancak olumsuz "hava" şartları tarafından engellenirler. Bu durum oyun içinde sıkça tekrarlanan bir beyitle anlam bulur. "Nev'i yabana attı bizi gerçi rüzgâr / Düştük hevâ-yı aşk ile bir özge âleme".

Aziz ve Muhsin de, büyük hevesle çıktıkları bu yolculukta düştükleri durumu kabul etmiş durumdadır ve realiteden kopuşun farkındadır. Ancak onların da elinden bir şey gelmez. O andan sonra başroldeki tek şey alkol ve yalan bir dünyadır artık. Aydınların bu hâle gelmesindeki sebebin, dönemin askerî darbesi olduğunu, oyun içinde Aziz'in bir diyaloğuyla okuyucuya verir Baydur.

Aziz: Üst katta emekli bir general oturuyor... Çok duyarl bir adam.

Alt katta oturan sessiz emekli ögretmene hiç benzemiyor (Baydur, 2009, 27).

Normal durumlarda, toplumda duyarlılık önce aydından beklenen bir özelliktir. Öğretmenlik mesleği de aydınlık yolu açmak görevinde ön basamaklardır ve onlar da toplumunun önünde seyrederler. Ancak, bu diyalogda görüldüğü üzere roller değişmiştir. Öğretmen sessizliğe bürünürken, duyarlı olma özelliği askere yüklenmiştir.

Oyunda yeniden değişen rollerde bu kez Necip her şeyin sahibi bir büyük, Aslı esrarengiz bir konuk, Muhsin ise bulutlu konuşan bir şairdir. Aziz alaycı bir kuzen konumunda iken, Engin'le Sevda evdeki evlatlık gibilerdir. Berfinaz teyze oyun boyunca tek değişmeyen kişidir. Yazarın deyimiyle, "onu değiştirebilecek bir oyun yazarı icat edilmemiştir henüz". Kişiler arasındaki sohbet bu kez Engin'in getirdiği Saka kuşuna isim vermek üzerinden devam eder. Kuş için, kimi saçma kimi hazin bir takım isimler önerilir. Teklif edilen "ölüm” ismi, aydınların hastalıklı ruh halini açığa vurur. Saka kuşunun kafesin içinde oluşu, oyun kişilerinin durumuyla paraleldir. Onlar da dört duvar arasında tutsak gibilerdir. Sonunda saka kuşunun adını Baykuş koymaya karar verirler. Necip'in anlattığı "oyuncuların masalı" da, aydınlar ve rejimin masalı olarak değerlendirilebilir. Bu masal, inançları uğruna iyi bir hayatı bırakıp, Goth kralına karşı duran oyuncuları anlatır. Onların bir kısmı, benimsedikleri inançtan türlü baskılara rağmen vazgeçmezken diğer kısmı ise, zarar görmemek için arkadaşlarına ihanet eder. Bu masalla, aydınların ne pahasına olursa olsun gerçeğin peşinden ayrılmaması gerektiği mesajı verilir. Darbe dönemindeki kimi aydınların da bu masaldakiler gibi olduğu anlaşılır. Onlar baştaki yönetimin değil, aklın kalemi olmak durumundadırlar.

İkinci perde farklı bir evde geçer. Bir tavan arası yahut bodrumdur. Eski, dantelli, tozlu eşyalar, apartman boşluğuna bakan demir parmaklıklı bir pencere ve bir sürü koltukla, ilk perde- 
nin aksi bir tablo çizer yeni dekor. Dikiş makinesi, tırpan, kazma, kürek ve bir çift çizme ve sahne ortasında bir soba vardır. Arka planda ise ilk perdenin tersine keman sesi değil ud sesi hâkimdir. O seçkin ortam, yerini alelade bir eve bırakmıştır.

Roller ikinci perdede de değişmiştir. Aslı ile Berfinaz teyze evde sohbet etmektedir. Aziz, annesi ile bale kursundan arkadaş olan Berfinaz teyzeyi ziyarete gelmiş bir makine mühendisidir. Aslı ile ilk kez orada tanışır. Engin ve Sevda da Berfinaz teyzenin komşularıdır ve evlidirler. Hatta yanlarında küçük kızları Limon da vardır. Muhsin ise istasyondan eve dönüp Aziz'i bulamayınca Berfinaz teyzeye gelmiş bir hukuk doktorudur yeni oyunda. Necip Bey, çöp koyarken kapı üzerine kapanınca Berfinaz'ın evine gelecek olan komşusu rolündedir. İkinci perde karakterlerin daha çok iç dünyalarına yöneldikleri bölümdür.

Oyun yine alkolün hâkim olduğu bir sohbetle, içinde bulundukları dönemden kesilen umutlar ve küçük Limon üzerinden geleceğe yönelik beklentilerle son bulur.

Engin: Limon'un sağllğına... Onu bekleyen güzel günlerin şerefine... kim bilir ne kadar çağdaş, ne kadar akill, bilgili, alıml, hoşgörülü, alçakgönüllü, duru ve güzel bir insan olacak kizım... Olağanaüstü bir dünya bekliyor onu... Her şeyin şimdikinden başka olacağ bir yeryüzü... Sahici insanların kurduğu gerçek tarihle, gerçek coğrafyanın kucaklaşttğı bir dünyada büyüyecek Limon ... kızım... (İçer) (Baydur, 2009, 71).

Sonuç olarak "Limon" oyununda, büyük heyecanlarla çıktıkları dünyayı değiştirme yolculuğunda, türlü baskılarla yıldırılarak düzenin parçası olmaya zorlanan aydının durumu gözler önüne serilir. Önceleri gerçeklerle yüzleşmeye korkan aydınlar, içki ve şakalarla bunlardan kaçmaya çalışırlar. Sonlara doğru ise içe dönüp yanlışlarına bakarlar ve geleceğe dair umut verirler.

\section{“Cumhuriyet Kızı” ve Yedi Profesörler}

Memet Baydur'un bu oyunu 1988/90 yılları arası İstanbul Şehir Tiyatroları, Ankara Devlet Tiyatrosu gibi önemli yerlerde sahnelenmiş ve büyük bir tartışmayı beraberinde getirmiştir. Oyun temelde, 1980 dönemi 1402 no.lu Sıkıyönetim Kanunu gereği görevlerinden ayrılan yedi profesörün ansiklopedi yazarak para kazanmak için toplandıkları evde, bir pavyon kadını olan Peri ile tanışmalarını anlatır. Oyun boyunca yazar, Peri üzerinden bir aydın eleştirisi yapacaktır.

Oyun zamanı, bir Aralık gecesi olarak tanımlanır. Olaylar bir apartman katının salonunda geçer. Tipkı "Limon" oyununda olduğu gibi, dekor estetik zevkin ürünüdür. Antika bir masa, rahat iskemleler, içi kitap ve içki dolu cam kapaklı dolabın yanı sıra, bir kanepe ve koltukla, dürbün, mikroskop gibi aletler; evin içindeki kişilerin akademik çevreden aydın insanlar olduğu izlenimi verir.

Yazar sahnede çeşitli hallerde bulunan yedi adamın gerçek olduğunu ve onları pek sevmediğini oyunun başında söylemekten çekinmez.

"Oyunun daha gerçekçi olmast için, bu yedi kişiliği/ya da kişiliksizliği kendi/asıl isimleriyle değil, başka isimlerle anacă̆ız bundan böyle. Sonunda kimin kim olduğu biraz karlşacak seyircinin aklında, ama atacağımı kurşun bir bumerang gibi yerini bulacak. Merak edilmesin!” (Baydur, 2009, 167).

Sahnedeki yedi adamdan Muvaffak "Matematik", Behçet "Sosyoloji”, Cafer "Fizik”, Abidin “Tarih”, Öztürk "Psikoloji”, Abbas “Zooloji”, Bünyamin ise "Biyoloji” profesörüdür. Yazmak zorunda oldukları yirmi iki ciltlik ansiklopedinin dokuzuncu cildini yazmaya çalışan profesörler, umursamaz ve alaycı şakalarıyla, bu işi pek ciddiye almadıklarını gösterirler. "Nasıl olsa 
kimse okumayacak”, “Ansiklopediler okunmak için değil, bakılmak için yazılır... dekoratif nedenlerle" fikirlerinde birleşen bu kof-aydın adamlar, umursamazlıklarının sebebini topluma bağlamakta, pek de haksız sayılmazlar. Yazım sürecinde oldukça düzensiz hareket ederler. Bir konuyu bitirmeden diğerine atlayıp eski yazdıklarından da hoşnut olmazlar. "Limon" oyununda olduğu gibi bu oyunda da içki önemli bir unsurdur. Onları gerçeğin boğuculuğundan uzaklaştırır, eğlenceli bir gevezeliğe iter. Ta ki beklemedikleri bir misafir kapıyı çalana kadar.

Profesörler "Yazar" maddelerinden sıkılıp "Balık Familyası"na geçmeye karar verdikten sonra konu üzerine tartışırlarken, dışarıda şiddetli bir gürültü duyulur ve kapı çalınır. Dışarıda kopan kıyametten memnun olmayan profesörler, kapıyı açıp açmamakta tereddüt ederler. Nihayet Bünyamin kapıyı açar ve içeri beyaz kürklü sarışın bir kadın düşer.

$\mathrm{Bu}$ kadın Peri isminde bir konsomatristir. Pavyonda çıkan kavgadan kaçıp rastgele bir kapıyı çalmıştır. Peri'nin eve gelişiyle erkekler arasında tartışma bir baş gösterir. Bazıları bu pavyon kadınının başlarına bela olacağını düşünürken, diğerleri onu güzel bulur. $\mathrm{Bu}$ durum karşısında evden ayrılmayı düşünenler dahi olur. Peri karakteri oyun boyunca, kendilerini çok önemli gören bu yedi adamın, önce modern insan görüntüsünün altındaki ilkel "erkek" yanı, sonra da aydın kabuklarının altındaki kofluğu ve çürümüşlüğü ortaya çıkaran kişi olacaktır.

Bir süre baygın yatan Peri, profesörlerin kendisi hakkında konuştuğunu duyarak uyanır. Dünyadan habersiz, hınzır ve çocuksu görüntüsünün aksine bu kadın karşı cinsi iyi tanıyan, hayat hakkında tecrübeli biridir. Eğitimsizliğine rağmen bu özelliği, profesörlere yönelttiği eleştirilerdeki en büyük silahı olacaktır. Peri'nin eve gelişinden sonra profesörlerin hemen hepsi, ona karşı yapay bir samimiyete bürünürler. Kendilerini önemli gören bu adamlar, sahip oldukları meziyetlerle, kendilerine sığınan pavyon kadınını etkilemeye çalışırlar. Durumdan rahatsız ama buna oldukça da alışkın olan Peri, daha baştan onları da çalıştığı pavyondaki müşterilere benzetir. Yalnız bir kişi, psikoloji profesörü Öztürk, Peri'den nefret eder ve sürekli onu aşağılar. Diğer profesörler oyun boyunca sırasıyla Peri ile yalnız kalıp onu etkilemeye çalışacaklardır. Bu durum Bünyamin ile başlar. Jazz'dan konu açan Bünyamin ile Peri’nin sohbetleri sırasında, Peri'nin gerçek isminin Pakize olduğunu öğreniriz. Bu durumu yadırgamayan Bünyamin'in aksine Pakize, ismin önemini vurgulayarak, ismin ne ise "o isim gibi davranırsın" der. Nitekim o dakikadan sonra pavyon kızı olan Peri gibi değil, -sonraları söyleyeceği- bir "Cumhuriyet Kızı" olan Pakize gibi davranacaktır. İlk perdenin sonu Pakize'nin Bünyamin üzerinden yaptığ 1 bir eleştiri ile biter. Kendine sürekli yaranmaya çalışan Bünyamin ve onun gibileri, özendikleri modern tipe ağır basan hayvani yönleri için eleştirir. Sunulanla yetinmeyi ve sadece ikram edileni görmeleri dolayısıyla onları tenkit eder. Kafasındaki sarı peruğu çıkararak ona firlatır. Çıkan sarı peruk ile pavyon kızı Peri’nin izi de şimdilik kaybolmuştur.

İkinci perdede dekor aynıdır ancak, yoğunlaştırılan kitap ve kâğtlardan, masaya eklenen yer yüzü küresi gibi yeni nesnelerden, zamanın biraz ilerlediğini anlarız. İlk perdenin sonunda Pakize'nin eleştiri oklarından nasibini alan Bünyamin yerine Abbas'ı görürüz sahnede. Pakize için hazırladığı yemek tabağını getirmiştir. Bu bölümde Pakize bir başka eleştiri başlığı açarak, Abbas nezdinde diğer aydınları pasif kalmakla suçlar. Abbas'ın "Böyle olsun ister miydik?" söylemine karşı Pakize, onların "hayatlarını koca bir patronun dikte ettiği gibi" yaşamalarından ve bunda mahzur görmemelerinden dem vurur. Gerçekten de sıkıyönetim kanunu ile işlerinden ayrılan bu adamlar, şimdi pasif bir konumdadırlar ve dışarı ses yükseltmeye korkarlar. Ansiklopedi yazımında, balık maddesini yazacakları sıra gelen "dil" balığının ismi bile onlara korku vermiş, gerçek dille ilgisi olmamasını temenni etmelerine sebep olmuştur.

Pakize, Abbas'a kendi eğitim durumunu anlatırken, eğitim sistemi ve eğitmenlere de bir eleştiri yöneltir. Okuldaki insanların da çalıştığı pavyondakilerden farkı olmadığını söylerken, 
yaşadığı hayal kırıklığı anlaşı1ır. Okulunu "suları akmayan, ekşi ayranla toz süt verilen ve ikide bir herkesin saçlarının sifir numara traş edildiği bir" yer olarak tanımlayan Pakize, öğretmenlerini de "uskumru suratl ve hafif blylklı bayan ögretmenler- pancar suratl, boyun damarlarl mosmor adamlar" olarak anlatır. Bu hüzünlü sohbet sırasında Abbas, aydın sorumluluğu gereği bir çözüm üretmek yerine, “erkek sorumluluğu” gereği, firsattan istifade Pakize'ye sarılmak ister. Ancak, kadının farklı tavrı ve Cafer'in zamansız gelişiyle sarılma gerçekleşmez. Abbas Cafer'i görünce odadan çıkar ve fizik profesörüyle Pakize arasında bir tahtakurusu muhabbeti başlar. Kötü kokulu ve insan kanıyla beslenen bu böceklerin hikâyesi Pakize'ye çevresindeki insanlarla bağ kurdurur. Cafer geldiği gibi kur yapmaya başlar. Şiirsi bir ses tonuyla, kadını buralardan götürme teklifinde bulunur. "Cumhuriyet Kızı" kimliğiyle bu sapmış aydınları uyandırmak için sert eleştirilerde bulunan Pakize, onların daha ziyade içlerindeki erkeğe önem verişi karşısında, zaman zaman pavyon kızı Peri rolüne dönerek pes eder. Aslında profesörlerin derdi kadını elde etmekten çok, bu yolda onu en çok etkileyen kişi olmak, övgü ve saygı kazanmaktır.

Darbe sonrası ortaya çıkan elitist ve şovenist burjuva-aydını görürüz onlarda. Topluma verecek bir şeyleri kalmamasına karşın, hala onlardan büyük görünme ve takdir edilme ihtiyacı duyarlar. Bu tavır karşısında Pakize, evdeki adamların kaçtığı adamlardan da kötü olduğu fikrine kapılır. Profesörlerin Pakize'yi elde etmek için kabarmaları, içlerinin kofluğundan başka bir şeyi göstermiyordur. Bu sözleri Cafer'e söylediğinde ise, fizik profesörü çoktan odadan kaçmıştır.

Cafer'den sonra odaya giren Behçet, Pakize'nin onları pek sevmediğini ve itip kaktığını fark etmiştir. Hâl böyleyken, neden hala burada olduğunu sorguladığında, Pakize'nin söylediklerini bir türlü anlamaz. Bunun nedeni, aydının halka inememesi sorunudur. Onların kafasında halk tabakasına açılan bir kapı yoktur. Pakize bir "Cumhuriyet Kızı" olduğunu vurgularken, onları aptal ve sığ bulduğunu söyler.

\section{Pakize: Çünki korkaksınız! Çünki kofsunuz! Kof! Çünki çürüksünüz! Çünki tedavisi artık çok zor olan bir aşağıllk duygusuyla kundaklanmışsınız! Çünki sırtınız sıvazlanmazsa, gazınız çıkartılmazsa, altınız değiştirilmezse ve üstüne üstlük, size meme verilmezse eliniz ayağınız dolaşıyor ... ne yapacă̆l- nızl şaşırılyorsunuz! (Baydur, 2009, 198).}

Pakize'nin bu sözleri; korkan, sinen ve artık topluma faydalı olamayan aydının, hala elit tavrını sürdürerek, topluma üstten bakmasına ve hala eskilerden gelen aydın profilinin ekmeğini yemesine bir eleştiridir.

Behçet'in bu eleştirilere "seni öpmek istiyorum" sözleriyle karşılık vermesiyle, Pakize'nin inancı biraz daha kırılır. Behçet' in gidişi ile Muvaffak gelir. Bir öncekinden farklı değildir olanlar. Öztürk'ün ikiliye dâhil oluşuyla ortalık karışır. Figürün, ikiliyi sevgili sanıp hakaret etmesi ile Muvaffak dışarı çıkar. Pakize ile tartışmalarından, onların birbirlerini önceden tanıdıklarını anlarız. Öztürk önceleri Pakize'nin çalıştığı pavyonun müdavimlerindendir ve bunun diğerlerince duyulmasını istemez. O adam, kendi kusurunu başkalarını ezerek örtmeye çalışan biridir. Entelektüel donanımına ek olarak bu yönü, onu en tehlikeli insan türü yapar. Onun gibileri bu ülkeye yarar sağlamaktan çok zarar verirler. Hem toplumsal hem de cinsel iktidarsızlığı, onu çevreye ve Pakize'ye karşı saldırgan yapar. Şiddetli bir tartışmanın ardından Öztürk gider. O dakikadan önce gerçeklerle yüzleşmekten korkan ve odadan kaçan profesörler, şimdi hatalarıyla yüzleşmek için geleceklerdir "Cumhuriyet Kızı"nın yanına. İlk gelen Bünyamin olur. Bir Kızılderili oyunu oynayarak gelen Bünyamin, sanayileşme ve sonrasında gelen emperyalizmin yalnızca yolları ve taşıtları değil, insanları da demirleştirdiğini anlatır. Demir silahların Kızıl- 
derilileri ya fermuarlara ya da konservelere dönüştürdüklerini söyler.

Bünyamin'in bu hikâyesi, rejim ile aydının durumunu anlatır niteliktedir. Demir silah, aydın bilgeliğine üstün gelmiştir. Bu yenilgiden sonra onlar ya isteğe göre bir fermuar gibi açılıp kapanacaklar ya da bir konserve kutusu içine mahkûm olacaklardır. Bu akıbetten çok korkmalarına rağmen, seçtikleri diğer yol da kendilerini istenmeyen sondan koruyamamıştır.

Abidin'le beraber, bu adamların içinde bulunduğu trajediyi daha yakından hissederiz. Akademik kariyerleri ve hayatlanı [b]ilim olan bu adamlar, topluma inecek vakti bulamamaktan yakınırlar. Tek dayanakları olan ders verme mutlulukları da ellerinden alınınca sersemlemişler ve sonunda birer mekanik kuklaya dönüşmüşlerdir. Ansiklopedi onların ellerindeki tek çıkış noktasidir.

Muvaffak:...Haklisını, öğrenmek ya da ögretmek için değil ansiklopedimiz. Kurtulmak için! (Sessizlik) Bir an olsun soluk alıp dinlenmek için duruyoruz bu ansiklopedinin klylsinda... Belki böyle bir şeyi yazarken, bir zamanlar bilim adamı olduğumuzu anımsayacă̆ız sanki... Sanki delikanlı olduğumuz günlerin şavkı vuracak üstümüze... Sanki yeniden insan olacağz. Korku bitecek. Zevksizlik bitecek. Kimlikler sessizce ortaya çıkacak. Sonra... onlar da bitecek! Biz... zaten bitmiş bulunuyoruz. Kim bilir... belki... (Seyircilere bakar) belki sizlere de bir şeyler kalır. Bu yokluktan! (Baydur, 2009, 218).

Sonuç olarak, "Cumhuriyet Kızı" Pakize tarafından yedi cüceleştirilen bu dev egolu adamlar, geleceğe dair yok denecek kadar az bir umutla kendilerini tüketmişlerdir. "Limon" oyununda Aziz'in kâğıda döktüğü mısralar gibi kendilerinden umudu kestiklerini belirten bu kalabalık, giderayak bir aydın sorumluluğu gereği seyirciye uyarıda bulunur.

\section{Fantastik Bir Kanun Adamı: “Maskeli Süvari”}

Yazım tarihi itibarıyla bu oyun, "Limon” ve “Cumhuriyet Klzı"ndan sonra gelir (1990). Yazarın, "Limon”da sisteme karşı çabalayan ancak ezilen, "Cumhuriyet Kızı"nda doğru yoldan şaşan, sahteleşen aydınları "Maskeli Süvari”de biraz daha kötü olarak karşımıza çıkacaktır. Onlar ne sisteme karşıdır ne de durumdan şikâyetçidirler. Kendilerine kurdukları yeni ve zengin dünyada yapma gerçeklikler içinde, maskelerle yaşarlar. Oyunda, aydın görünme çabasındaki üç burjuvanın maskelerinin, gizemli bir şekilde ortaya çıkan "Maskeli Süvari” tarafından düşürülmesi konu edilir. Diğer karakterler; Aşkın, Atilla, Melda ve Mine’dir.

Mekân bir açık hava tiyatrosunun barıdır. Sahnede Ortaçağ ile karışık bugünü gösteren bir dekor hâkimdir. Yirmili yaşlarda tıp son sınıf öğrencisi olan Aşkın burada barmenlik yapmaktadır. Arka fondaki arya, yukarıda icra edilen operadan gelmektedir. Antik tiyatroda yapilan operayı merak ederek gelen Atilla, Mine ve Melda sıkılır, bara bir şeyler içmeye gelirler. Zaten bu üç insanın orada olma sebepleri duydukları opera aşkı değildir. Operadan pek anlamadıkları, Atilla'nın blucinli ve kravatsız giyiminden belli olur. Bara indiklerinde içki eşliğinde bir "aydın gevezeliğiı"ne girişirler. Sohbete Aşkın'ın da katılmasıyla onların, hayatlarında bir heyecan aramak için orada olduklarını öğreniriz. Eski farklı yaşamlarını kaybetmekten, geçmişteki gibi olamamaktan dem vururlar. Onlar bulundukları konuma gelirlerken, kimliklerinden sıyrılmıs ve toplumdan kopmuşlardır.

Atilla: Sahi, yıllardır elimi bile sürmedim bir şiir kitabına...

Melda: Korkunç bir şey bu! Dünyanın en uzun yürüyüşlerini biz yapardık

bir zamanlar. 
Atilla: Ben de hatırlyyorum o günü... Ülkemizdeki en eski ve en güzel tavirlardan birini anlatmıştım size.

Melda: Yere düşmüş bir ekmek görünce onu öpüp başına koyan ve bir duvarın üstüne, yükseğe usulca birakan insanlardan söz etmiştin.

Atilla: Küçükken ben de öyle yapardım ... (Baydur, 2009, 276- 277).

Yazar bu üç burjuvayı sert bir şekilde eleştirmesine rağmen, onları okuyucunun/izleyicinin gözünde çok da düşürmek istemez. Neden bu hale geldiklerini açıklamalarına izin verir.

"Limon" oyunundaki yolculuk teması, farklı bir boyutta, bu oyunda da karşımıza çıkar. O, aydınlar için büyük bir beklentiyi ve aynı büyüklükte bir yıkımı temsil eder.

\begin{abstract}
Atilla: Büyüdüğ̈̈m için değil Melda... İçimde bir şeyler kırıldı sanki. Yüzylllardır beklediğim ve geleceğine inandı̆̆ım bir otobüs gelmedi sanki.

Melda: Otobüsün icadı o kadar eski değil!

Atilla: Düşsel bir otobüsten söz ediyorum.

Mine: Frenleri patlayıp içindeki bütün yolcularıyla uçuruma yuvarlanan

Kristal Yolculuk Şirketi'ne ait havalandırmalı Güzel Günler Otobüsü'nden söz ediyorsun di mi? (Baydur, 2009, 277).
\end{abstract}

Onlar, dönem şartlarıyla yollarını değiştirmişler ve aydın olma otobüsünü kaçırarak yanlış yola sapmışlardır. Aşkın, bu yakınmalara karşı bir eleştiri geliştirir ve onları pasif olmakla suçlar. Yitirilmesinden şikâyet ettikleri bu büyüyü yaratacak tek kişi kendileridir. Ancak üretmeyi durdurdukları için bunu yapmaları çok da mümkün değildir. Bu genç adama göre, özlemini çektikleri şeyleri yine onlar icat edebilirler. O, oyunda ideal, sorumlu insan tipini çizer. Aynı zamanda geleceğin beklenen aydınıdır. Sohbet sürüp içkiler yudumlanırken sahnenin sağ tarafından, "Diz boyu siyah çizmeler, siyah dar bir pantolon, siyah bol bir gömlek, beyaz-dantelli bir yaka. Pırıl pırıl kabzalı bir kılıç" ile tarif edilen "Maskeli Süvari” girer. "Doğal olarak maskelidir. Garip bir maske. Siyah, geniş kenarl şapkasıyla tamamlaninca güzel, korkutucu, gülünç, gerçek bir masal kahramanı. Şapkası beyaz ve büyük tüylerle süslüdür. Uzun ve klzll-kestane rengi saçları vardır Maskeli Süvari’nin”.

“Maskeli Süvari”nin gelişi ile oyun hareketlenir. Herkes onun operada yer alan bir figüran olduğunu düşünür. Aşkın ise şaşkındır ve bu gizemli yabancının nasıl geldiğini merak eder. Çünkü geldiği sağ taraf uçurumdur ve bir giriş yoktur. Diğerleri bu durumla pek ilgilenmezler. Özellikle Atilla, Maskeli ile sürekli dalga geçer, kendince onu ezmeye çabalar. "Maskeli Süvari" gizemli duruşu ve sözleriyle Atilla hariç herkesi etkisi altına alır. O, Melda'nın gördüğü kötü bir rüya yüzünden uykusuz oluşunu bilir. Genç kadının rüyasını açıklar. Maskeli’yi ilk gördüğü anda ona hayran olan ve öpmek isteyen Mine'nin dudaklarına bir buse kondurur. Herkesin en bilinmeyen sırlarını gün ışığına çıkaran ve yüzleştiren bu gizemli yabancı, başka bir zamandan ve iki bin yaşın üstünde olduğunu sezdirir. İtalyan ressam Leonardo Da Vinci'den William Shakespeare'e, İbrahim Müteferrika'dan George Bernard Shaw'a birçok tarihi sima ile ahbaplık ettiğini söyler. Tüketim çılgını genç kadınlar Mine ve Melda, Maskeli’ye karşı bir aşk duyduklarını düşünürler. Herkes onun maskesini çıkarmasını ister, kim olduğuyla alakalı tahminlerde bulunur.

Aşkın “Maskeli Süvari”ye düşünsel anlamda en yakın insandır. Goethe'nin "Son üç bin yılda olan her şeyin hesabını kendi kendine veremeyen her insan, karanlıkta kalmaya, deneyimsizliğe, gününü gün ederek yaşamakla yükümlüdür” sözü, oyun karakterlerinin iki kutbunu gösterir. Maskeli, Aşkın'a sorgulamak ve üretmek için gerekli gücü verir. Zira onun görevlerin- 
den biri de budur.

"Maskeli Süvari"; Atilla, Mine ve Melda için bir sorgulayıcıdır. Onları bir kanun adamı edasıyla ve masalsı bir şekilde gerçekleriyle yüzleştirir. Onları karanlık uykularından uyandırmak ister. Atilla'ya karşı diğerlerinin desteğini kazanır. Mine ve Melda ondan etkilenmesine karşın, sözlerini onu bir sanatçı sanarak anlamadan dinlerler. Nitekim eleştiri okları genç kadınlara çevrilince onlar da Maskeli’ye tavır alacaklardır.

Maskeli, çoğunlukla gülünç duruma düşürdüğü Atilla'ya yer yer ufak çapta şiddet uygular. Atilla'nın barbarlık eleştirilerine karşı Maskeli'nin verdiği cevap aynı zamanda bir sanatçı tanımıdır. Gizemli Süvari bir sanatçı olmadığını açıklamaya çalışırken aynı zamanda onlara karşı olan sevgisinden bahseder. O, sanatçılardan "yalnızca şiddete başvuran kişiler" olarak bahseder. Şiddetin de sanat gibi kalıcı olduğunu belirtir. Onun şiddet anlayışı bir algı durumudur. Dünya ve zamana ait her şeyi, geçmiş ve geleceği bütünüyle algılamak ve bu algıyla başlayan bir duygudur şiddet.

Maskeli: Italyan bir dostum vardl... bir... ressam diyeceğim ama dilim varmıyor... kuşlardan başka hiçbir şeyin uçmadığı günlerdi ve dostum "uçak” yapmaya çalışıyordu. (Sessizlik) Bu şiddetli bir şey değil mi sizce? (Baydur, 2009, 288).

Metnin devamında karakterler arasında bir soru sorma oyunu yapılır. Maskeli böylece üç burjuva aydını sorgulamaya başlar. Aşkın da oyun boyunca Maskeli ile beraber onlara sert eleştiriler yöneltir, alay eder.

Mine ve Melda Atilla'ya göre daha açık olmalarına karşın fazla romantiklerdir. Asıl gerçekliği merak etmezler, doğrunun peşinde koşmaz ve var olanla yetinmeyi tercih ederler. $\mathrm{Bu}$ özellikleriyle "Cumhuriyet Kızı"ndaki profesörleri andırırlar. Hâlbuki aydın denen kişinin en büyük özelliği bitmeyen merakı ve şüpheciliğidir. Kendisine sunulanla yetinmez ve sürekli gerçeğin peşinde koşar. Tüm bunlara bakarak, oyun kişilerinin ne kadar aydın vasfina sahip oldukları sorgulanabilir.

Mine ve Melda gibileri eleştiriye kesinlikle kapalıdırlar. Âşık oldukları Maskeli tarafından eleştirilince ona da tavır alırlar. Maskeli, Mine ve onun nezdinde diğerlerini, her şeyi biraz bilmek ama hiçbir meseleye kafa yormamak, hiçbir şey üretememekle suçlar. Aynı eleştirileri Aşkın da yer yer tekrarlar. Bu üç aydın, kılıcı boyunlarında gördüklerinde korkar ve sinerler. Baskıya hemen boyun eğerler. Bu durum, Goethe ile tanıdığımız aydın profiline ters düşer. Oyun kişilerine aydındır diyebilmek, bu sebeplerden dolayı çok da mümkün değildir.

Darbe döneminin yarattığı bu yeni tipler, baskı altında farklı yollara itilmişlerdir. Bu oyunda yer alan burjuvalar, girdikleri yolda tasasız yaşamak derdindedirler. Baskı görmemek için düşünmez, ses yükseltmezler. Onlar için üretim geri planda kalmıştır. Kendi dünyalarında hiçbir şey için bedel ödemeden yaşamak isterler. Bu durum yazar tarafindan katlanılamazdır ve maskeli kahraman onları kendilerine getirmek için binlerce yıl uzaktan getirilir. Bu uyarının gerçek hayatta, dönem şartları içinde herhangi bir kimse tarafindan yapılamayacağı düşünüldüğünde, sahne üzerindeki fantastik bir kahraman tarafından yapılması anlaşı1ır bir durumdur. Nitekim yazar, tiyatronun ve oyuncunun etkisini iyi bilen biridir.

Maskeli, kelime oyunları yaparak onlara gerçekliği anlatma gayretine girişir. Maskeli'ye göre gerçek ikiye ayrılır. "Ger" ve "Çek” "Her gerçek önce çarmıha gerilir" sözü gerçeklerin acı getireceğini anlatmasını simgeler. Yazara göre bu acılara rağmen gerçeklerden vazgeçilmemesi gerekir. Gerilerek "ger-ginleşen gerçeğin eline verilen çek, bütün gerginliği geçirir ve geriye, geri kalmış bir gerçek kalır”. İşte bu burjuvalar da ger-çek'in çek kısmındadır ve sahip 
oldukları zengin yaşamla gerginliklerini üzerlerinden çoktan atmışlardır.

"Maskeli Süvari" bu şekilde oyun boyunca kendini aydın sanan bu insanların maskelerini teker teker düşürür. Ziyaret ettiği bu amfi tiyatroda, geçmiş üç bin y1lla köprü olabilecek tek kişi olarak Aşkın'ı görür. Gitmeye karar vermeden önce, Atilla, Mine ve Melda'ya tavsiyelerde bulunur. Onlardan kimliklerini bir an önce seçmelerini ister. İnsan, çevresini ne kadar kandırırsa kandırsın, başını yastığa koyunca gerçeklerle yüzleşecektir ve kendini kandırması mümkün değildir. Maskeli gitmeden önce 1srarlar karşısında maskesini çıkarır ancak her yeni maskenin altından yenisi çıkar. Bu onun somut bir kişilik olmadığının kanıtıdır.

Oyundaki Maskeli karakterin tam olarak kim veya ne olduğu yazar tarafından söylenmez. Okuyucunun/izleyicinin onu kendince yorumlaması, anlamlandırması gerekir. O, kimileri için bir ilham kimileri içinse geçmişten tutulan bir 1şıktır. Aynı zamanda darbe döneminin yarattı̆̆ bu burjuva aydın takımı için bir uyarıcıdır. Oyunun sonunda Maskeli Süvari giderken üç kişide hiçbir değişim yoktur. Giden kahramanın ardından yine alaycı bir şekilde bakarlar.

Memet Baydur'un diğer oyunlarında olduğu gibi "Maskeli Süvari”de de bir sorgulayıcı karakter üzerinden aydın sorgusu yapılmıştır. Yazar, bir yandan, topluma yön vermesi gereken beyinlerin, üstüne çekilen örtüyle kayboluş hikâyesini anlatırken, diğer yandan, onların yokluğunda boşalan "aydın" sıfatını sahiplenmeye çalışan burjuvaların sefaletini gözler önüne serer.

Oyundaki sorgulayıcı karakterlerin aslında bizzat bu insanlar tarafından yaratıldığı söylenebilir. "Cumhuriyet Klzı"ndaki Peri'nin, bilinçli biri olmasına karşın pavyona düşmesi, "Maskeli Süvari”nin erdeminin ancak bir masal karakterinde varolması ve küçük "Limon"un geleceğinden duyulan endişe, üzerine düşen sorumlulukları bir şekilde yerine getir(e)meyenler yüzündendir.

\section{Sonuç}

12 Eylül darbesi, toplumun lokomotifi olması beklenen aydını, görevinden alıkoymuş tarihi süreçlerden biri olmuştur. Baskıya direnç gösteremeyen aydınlar, bir içedönüş yaşamışlardır. Bu sıkıntılı süreç yalnızca toplumun iyi beyinlerini sindirmekle kalmamış, aynı zamanda yeni -ve sahte-, aydın tiplerinin doğuşuna da zemin hazırlamıştır. Var olanların bazıları üretimi durdurup geçmişin kaymağını yemek isterken, doğan boşlukta, Türk toplumunun burjuvaları da kendilerine bu sıfatı layık görmeye başlamışlardır.

Memet Baydur'un hemen her oyunu bu olumsuz koşullar ve bunların sonuçları üzerine kurgulanmıştır. Yazarın toplumsal sorunları sanatına konu etmesindeki amaç, tiyatroya olan inancı olmuştur. Ele aldığımız üç oyun da benzer özelliklere sahiptir. Baydur, sorunlu karakterlerin yanına mutlaka onları eleştiren, maskelerini düşüren, iç hesaplaşmaya teşvik eden masum -aslında mağdur- bir karşı karakter koymuştur. Oyunda karakterler arasındaki ilişki, suçlumağdur ilişkisi olarak da düşünülebilir. Bunun yanında, hepsinde tamamlanmamış, mecâzi bir yolculuk fikri vardır. Üç oyunda da, eleştirilen tipler nedenleriyle kendilerini savunurlar.

Baskıcı rejimle sinen, yalnızlaşan ve yabancılaşan Aziz, "Limon" oyunundaki problemli aydın tiptir. Muhsin ve Necip de ikincil problemli tipler olarak sayılabilir. Yazar bu karamsar insanları yeniden düşündürmek ve kendine getirmek için Aslı'yı kullanır.

“Cumhuriyet Klzı”nda yer alan yedi profesörün görevlerinden uzaklaştırılmaları üzerine üretimi durdurmaları, Baydur için kabul edilemez bir durumdur. İçleri çürümesine karşın, edindikleri aydın postları çıkartmayı reddeden bu yedi adam, bir pavyon kadını olan Peri/Pakize vasıtasıyla hicvedilir. Toplumun farklı tabakalarından bu kişiler oyun içinde karşılaştırılarak aynı zamanda bir "pavyon- elitist” çatışması da yaratılır.

“Maskeli Süvari," kendini çok değerli gören üç burjuvayı okuyucunun gözü önünde yerle bir eder. İktidara ses yükseltmeyi başaran Goethe, insanlığa basamak atlatan Da Vinci, Shakespeare 
gibi isimlerle günümüz aydın tiplerini aynı metne sokarak bizlere aradaki uçurumu gösterir.

Sonuç olarak, yazarın darbe dönemi aydınlarına yönelik eleştirisi sistematiktir. Her kare ve mesaj, bir bütünü tamamlar niteliktedir. O, pasif ya da sahte aydın istemez. Güç karşısında dik durup “J’Accuse! ” (Suçluyorum!) demeyi başaran Goethe gibi aydınları arzular.

Düzgün Türkçesi, akıcı üslubu ve geniş bilgi donanımıyla önemli bir sanat adamı olan Memet Baydur, kendini bir aydın olarak görerek bu minvalde hareket etmiştir. Güçlü gözlemi, akıllı kurgusu ile yazar, bizlere derdini bol örnekli ve canlı sahnelerle anlatmayı başarmıştır. Darbe dönemi sonrası en üretken isimlerden olan Baydur'u okumak, o buhranlı dönemin psikolojisini bizlere biraz olsun hissetme imkânı tanırken, "aydın" kavramına bakışımızda da yeni bir perspektif oluşturacaktır.

\section{KAYNAKÇA}

Baydur, M. (2009). Tiyatro Oyunları. İstanbul: İletişim Yayınları.

Baysan, G. T. (2002). "Gerçek ve Adalet Savaşçısı Zola". Hacettepe Üniversitesi Edebiyat Fakültesi Dergisi, 19 (1), 181-195.

Devellioğlu, F. (2007). Osmanlıca - Türkçe Ansiklopedik Lûgat Eski ve Yeni Harflerle. Yay. Haz.: Aydın Sami Güneçal. Ankara: Aydın Kitabevi.

Kılıçbay, M. A. (Temmuz 1995). "Türk Aydınının Dünyasını Anlamak”. Türk Aydını ve Kimlik Sorunu. Haz.: Sabahattin Şen. İstanbul: Bağlam Yayınları.

Mardin, Ş. (Kış, 1984). “Aydınlar Konusunda Ülgener ve Bir İzah Denemesi”. Toplum ve Bilim, 24, 9-16. Meriç, C. (2007). Mağaradakiler. İstanbul: İletişim Yayınları.

Şener, S, Yüksel, A., \& Elmas, F. (2002). Elveda Dünya Merhaba Kâinat. İstanbul: Mitos Boyut Yayınları. Yüksel, A. (1997). Çağdaş Türk Tiyatrosundan On Yazar. İstanbul: Mitos Boyut Yayınları.

“Aydın ve Toplum II” 02 Kasım 2013 tarihinde şu kaynaktan alınmıştır: www.emeginsanati2.blogcu. com/ adil-okay-aydin-ve-toplum-ii/5507059 
